\title{
Food Eaten by Four Species of Rodents in Polluted Forests
}

\author{
Zofia GEBCZYŃSKA, Marek GEBCZYŃSKI, \\ Krystyna MORZUCH \& Dorota M. ZIELIŃSKA
}

\begin{abstract}
Gębczyńska Z., Gębczyński M., Morzuch K. \& Zielińska D. M., 1989: Food eaten by four species of rodents in polluted forests. Acta theriol., 34, 32; $465-477$ [With 6 Tables]

The composition of diet was studied in Clethrionomys glareolus, Apodemus agrarius and Apodemus flavicollis in forests of Upper Silesia (southern Poland). The rodents were obtained from two polluted forested sites (Aniołki and Szczygłowice, the first site much more heavily polluted) except for $M$. agrestis which was collected only on more polluted site (Aniołki). The composition of diet within particular rodent species was fairly similar on both sites nevertheless differed from diets reported for other populations. C. glareolus fed on green parts of plants (45-67\% of diet) and on seeds and fruits $(21-38 \%)$. The absence of animal food and lack of seasonality distinguished these populations from all previously studied populations. A. agrarius fed mainly on green parts of plants $(90-94 \%$ in spring, $56-67 \%$ in autumn) while seeds constituted $24 \%$ of autumn diet. Thus this species elsewhere taking mainly seed and animal food changed its food habits entirely. A. flavicollis apart from seeds and animal food fed also on underground parts of plants (up to $50 \%$ of food volume). M. agrestis showed similar food preferences on Silesian locatios as in other parts of its range of distribution In spring, the green parts constituted $78 \%$ while in autumn its fraction fell to $43 \%$ with seeds making up $22 \%$. The presence of fungi $(26 \%$ of the diet in autumn) seems to be peculiar for the populations under study. Thus, there were alterations in diet in all four species compared with many European populations studied so far. In C. glareolus, M. agrestis, and A. flavicollis the changes occurred as shifts in proportions of principal components while in A. agrarius there were profound changes in the principal composition of diet.
\end{abstract}

[Institute of Biology, Warsaw University Branch in Białystok, Świerkowa 20B, 15-950 Białystok, Poland]

\section{INTRODUCTION}

The effects of industrial activity on the environment are diverse. Dustfall and gaseous emission entail air, water and soil contamination. Wherever mines operate, heaps of waste material accumulate, ground subsides, sometimes artificial water reservoirs are created. Such disruption to the environment can easily be noted throughout Upper Silesian region. All these effects precipitated by the development of heavy industry and mining bring about drastic changes in vegetation cover (Celiński \& Wika 1980; Celiński et al., 1982), and invertebrate populations (Dąbrowska-Prot, 1982), and also in vertebrate populations including rodents (Walkowa et al., 1982; Chełkowska et al., 1985). Changes in plant species composition, the age structure of plant populations and also in fruit and seed production cause direct 
changes in composition and volume of food supply for herbivores inhabiting such areas. It may be thus presumed that such changes will alter the diet in local rodent species. The aim of this study was to study any effects which environmental pollution might exert on feeding relationships in four most common species of forest rodents.

\section{STUDY AREA, MATERIAL AND METHODS}

The study was carried out in Rybnik Coal Basin of Upper Silesian region of southern Poland. There were two plots involved. First, at Aniołki, covered by a transformed form of Tilio-Carpinetum with Carex bryzoides L., Rubus caesius L. and Pteridium aquilinum L. This area was heavily inundated because of earth subsidence. Second plot, at Szczygłowice, at 10 kilometre distance from the first one, is also covered by Tilio-Carpinetum with Carex bryzoides and Pteridium aquilinum.

The effects of industrial activity and related disruption to environment varied between the two plots (Table 1). The Aniołki plot had (a) much more degraded vegetation, (b) different number of plant species, (c) higher degree of coverage by herbs and (d) higher degree of coverage by fallen trees and branches.

Both plots were inhabited by the same species of rodents: the bank vole Clethrionomys glareolus (Schreber, 1780), the field vole Microtus agrestis (Linnaeus, 1761), the yellow-necked mouse Apodemus flavicollis (Melchior, 1834), and the striped field moruse Apodemus agrarius (Pallas, 1771). The harvest mouse Micromys minutus (Pallas, 1778), the dormouse Muscardinus avellanarius (Linnaeus, 1758), and the domestic mouse Mus musculus Linnaeus 1758 were found in the area in much lesser numbers (Walkowa et al.,1982; Chełkowska et al., 1985). First four species were abundant although their numbers on two plots differed. Several years of trapping revealed that Aniołki rodent fauna is dominated by $M$. agrestis (up to 70 inds $\mathrm{ha}^{-1}$ ) and $A$. agrarius (up to 30 inds $^{-1}$ ). At Szczygłowice C. glareolus dominated (up to 70 inds $\mathrm{ha}^{-1}$ ). A. flavicollis was relatively scarce on both plots (Walkowa et al., 1982; Chełkowska et al., 1985).

The rodents for this study were collected in spring and autumn by means of baited snap traps. Their stomachs were removed and kept in $4 \%$ formaldehyde solution. The total number of 249 stomachs were examined. The contents of each stomach were placed on a watch-glass with a few drops of water and Lugol reagent $\left(\mathrm{J}_{2}\right.$ in $\left.\mathrm{KJ}\right)$ for starch staining. After mixing, four microscopic glycerin slides were prepared from each stomach. The microscopic ocular fitted with 100-square grid was used to determine the number of squares occupied by a given food type to determine its relative abundance.

Histological preparations, drawings of various types of epidermis and test slides obtained from stomach contents of rodents fed in the laboratory were used for identification of plant species. Animal food was identified by features of undigested remnants of chitin covers, parts of extremities and single complete specimens.

\section{RESULTS}

\subsection{The Bank Vole}

In spring, the bank voles collected at Aniołki fed on 24 plant species, most frequently on Betula $s p$. and Majanthemum bifolium (Table 2).The green parts of plants made $64 \%$ of the volume, seeds and fruits $-23 \%$, with roots and tree-bark $(4 \%)$ and animal food $(2 \%)$ making 
Table 1

Characteristics of Aniołki and Szczygłowice study plots (after Walkowa, Adamczyk \& Chełkowska, 1982).

\begin{tabular}{lcc}
\hline Index & Aniołki & Szczygłowice \\
\hline Dust fall, $\mathrm{t} / \mathrm{km}^{2}$ per year & 165 \\
Mean number of all plant species per trapping point & 450 & 8.4 \\
Mean number of plant species in herb layer per & 12.8 & 5.4 \\
trapping point & 10.2 & 101 \\
Sum per cent herb layer coverage & & 49.0 \\
per trapping point & 157 & 10.8 \\
Per cent undergrowth coverage per trapping point & 18.1 & 26.9 \\
Per cent coverage with fallen trees and dry branches & & \\
\hline
\end{tabular}

1 After Foik (1978) and Warteresiewicz (1979).

2 Percentage cover by individual plant species were summed.

up total. In autumn, out of 19 plant species eaten most frequent were Pteridium aquilinum and Sorbus aucuparia. The quantitative make-up of diet volume was similar to that in spring with green parts contributing in $59 \%$, seeds and fruits - in $21 \%$, fungi - $5 \%$, and other components below $0.3 \%$.

At Szczygłowice, the voles fed mainly on green parts $(52 \%)$, also on seeds and fruits $(36 \%)$, roots and tree-bark $(3 \%)$, and animal food below $1 \%$. The list of eaten species covered 18 species with Frangula alnus, Betula sp. and Sorbus aucuparia on top. In autumn, the green parts constituted $45 \%$ of diet, seeds and fruits - $38 \%$, roots and treebark $-2 \%$ and fungi $0.7 \%$. Betula sp. and Sorbus aucuparia were the most preferred species from the list of 17 species (Table 2). It should be added that some species were eaten in large quantities by almost all individuals. In particular, there were some seeds and fruits found in almost every stomach examined. However, some plant species, although found in small quantities, occurred in many species (e.g. Carex bryzoides, Impatiens sp., Table 2).

\subsection{The Field Vole}

The specimens were collected only at Aniołki site and were found to eat $78 \%$ of green parts, $9 \%$ bark, and $3 \%$ of animal food. Calamagrostis sp. and Rubus sp. were most preferred plant species (Table 3). In autumn, the percentage of green parts in diet dropped significantly (to $43 \%$ ) with simultaneous increase in fungi (as much as $26 \%$ ) and seeds $(22 \%)$. Animal food constituted $1.3 \%$ of the diet. The most preferred plant species in autumn were Carex bryzoides, Deschampsia caespito$s a$ and other grasses. The list of species found in stomachs covered 18 species in all. 
Table 2

Percentage and frequency of occurrence of food components in Clethrionomys glareolus in spring and autumn at Aniołki and Szczygłowice forest sites.

Number of samples ( $\mathrm{n}$ ) is shown. A, percentage of diet component in stomach contens; $\mathrm{B}$, percentage of stomachs containing given component.

\begin{tabular}{|c|c|c|c|c|}
\hline \multirow[b]{2}{*}{ Kind of food } & \multicolumn{2}{|c|}{ Aniołki } & \multicolumn{2}{|c|}{ Szczygłowice } \\
\hline & $\begin{array}{c}\text { Spring } \\
\mathrm{n}=31 \\
\mathrm{~A} / \mathrm{B}\end{array}$ & $\begin{array}{c}\text { Autumn } \\
n=24 \\
\text { A/B }\end{array}$ & $\begin{array}{c}\text { Spring } \\
\mathrm{n}=23 \\
\mathrm{~A} / \mathrm{B}\end{array}$ & $\begin{array}{c}\text { Autumn } \\
\mathrm{n}=31 \\
\mathrm{~A} / \mathrm{B}\end{array}$ \\
\hline Ajuga reptans $\mathrm{L}$. & $1.2 / 3$ & 一 & - & \\
\hline Amelanchier ovalis Med. & - & - & $1.0 / 12$ & $0.7 / 23$ \\
\hline Athyrium filix-femina (L.) & $1.0 / 13$ & $3.4 / 25$ & $0.2 / 4$ & $0.5 / 13$ \\
\hline Betula sp. & $14.3 / 45$ & $6.5 / 17$ & $9.2 / 57$ & $12.8 / 55$ \\
\hline Calamagrostis sp. & $1.6 / 26$ & $2.0 / 7$ & - & - \\
\hline Carex brizoides L. & $1.0 / 13$ & $0.4 / 13$ & $1.3 / 22$ & $1.5 / 45$ \\
\hline Drypoteris sp. & $1.2 / 19$ & $1.9 / 42$ & $1.1 / 9$ & - \\
\hline Equisetum sp. & $0.1 / 7$ & - & - & \\
\hline Evonymus europaea L. & - & - & - & $0.5 / 7$ \\
\hline Festuca gigantea (L.) Vill. & $0.4 / 10$ & - & $0.2 / 9$ & $0.6 / 9$ \\
\hline Frangula alnus Mill. & $3.1 / 23$ & $0.3 / 13$ & $20.5 / 83$ & $5.6 / 68$ \\
\hline Galeopsis sp. & $1.5 / 3$ & -10 & $0.1 / 4$ & - \\
\hline $\begin{array}{l}\text { Impatiens sp. } \\
\text { Luzula nilosa (L) Willd. }\end{array}$ & $1.0 / 32$ & $2.5 / 21$ & $0.8 / 30$ & $2.0 / 39$ \\
\hline $\begin{array}{l}\text { Luzula pilosa (L.) Willd. } \\
\text { Lysimachia vulgaris L. }\end{array}$ & $1 . \overline{0} / 10$ & $\begin{array}{l}0.8 / 4 \\
0.4 / 4\end{array}$ & $0 \overline{1 / 4}$ & $\overline{21} 7$ \\
\hline $\begin{array}{l}\text { Lysimachia vulgaris } \mathrm{L} \text {. } \\
\text { Majanthemum bifolim (L.) }\end{array}$ & $8.6 / 32$ & $0.47]^{0}$ & $0.04 / 4$ & 0.217 \\
\hline Moeohringia trinervia (L.) & $0.4 / 10$ & - & - & 二 \\
\hline Oxalis acetosella $\mathrm{L}$. & $1.2 / 23$ & $2.0 / 25$ & $0.3 / 9$ & $0.3 / 9$ \\
\hline Populus tremula L. & - & - & $0.4 / 9$ & - \\
\hline Potentilla sp. & - & $2.5 / 13$ & - & - \\
\hline Pteridium aquilinum (L.) & $6.2 / 65$ & $15.2 / 75$ & $4.2 / 52$ & $5.1 / 55$ \\
\hline Quercus robur L. & $6.3 / 65$ & $4.0 / 21$ & $3.5 / 57$ & $0.2 / 13$ \\
\hline Rubus sp. & $3.3 / 23$ & $1.0 / 13$ & $0.6 / 9$ & $3.5 / 39$ \\
\hline Scrophularia nodosa L. & $0.9 / 13$ & $1.7 / 17$ & - & $0.1 / 3$ \\
\hline Senecio sp. & $0.9 / 13$ & $1.6 / 17$ & $\overline{5} \overline{144}$ & $0.2 / 3$ \\
\hline Sorbus aucuparia L. & $6.8 / 32$ & $8.0 / 54$ & $8.5 / 44$ & $11.2 / 65$ \\
\hline Stachys silvatica L. & $0.5 / 10$ & $2.8 / 7$ & - & $0.3 / 10$ \\
\hline $\begin{array}{l}\text { Trientalis europaea L. } \\
\text { Urtica dioica L. }\end{array}$ & $\begin{array}{l}0.3 / 16 \\
0.8 / 25\end{array}$ & $\underline{0.8 / 8}$ & 二 & 二 \\
\hline $\begin{array}{l}\text { Urtica dioica L. } \\
\text { Seeds and fruits }\end{array}$ & $\begin{array}{r}0.8 / 25 \\
23.3 / 75\end{array}$ & $20.6 / 100$ & $35.6 / 91$ & $37.5 / 100$ \\
\hline Roots and bark & $3.8 / 42$ & $0.3 / 8$ & $3.3 / 70$ & $2.1 / 16$ \\
\hline Fungi & $\overline{-1}$ & $5.2 / 21$ & $1.5 / 9$ & $0.7 / 10$ \\
\hline Animal food & $1.7 / 10$ & $0.2 / 8$ & $0.8 / 22$ & $\overline{10}$ \\
\hline Unidentified & $7.7 / 65$ & $15.9 / 71$ & $6.4 / 52$ & $14.4 / 68$ \\
\hline
\end{tabular}

\subsection{The Striped Field Mouse}

The green parts of plants dominated decisively in the diet of this species (in spring at Aniołki it constituted almost $90 \%$ of diet). Among the species preferred were: Rubus sp., Pteridium aquilinum and Frangula alnus with each constituting no less than $10 \%$ of the diet (Table 4). The animal food made $7 \%$ of the spring diet. In autumn, the preferences followed similar pattern but the percentage of seeds and fruits increased markedly (to $24 \%$ ) although the green parts of plants still dominated at $66.8 \%$ (Table 4 ). 
Table 3

Percentage and frequency of occurrence of food components in Microtus agrestis in spring and autumn at Aniołki forest sites. Explanations see Table 2.

\begin{tabular}{|c|c|c|}
\hline Kind of food & $\begin{array}{c}\text { Spring } \\
\mathrm{n}=13 \\
\mathrm{~A} / \mathrm{B}\end{array}$ & $\begin{array}{c}\text { Autumn } \\
\mathrm{n}=16 \\
\mathrm{~A} / \mathrm{B}\end{array}$ \\
\hline Agrostis canina L. & $0.8 / 15$ & $0.3 / 17$ \\
\hline Betula verrucosa Ehrh. & $1.8 / 31$ & - \\
\hline Calamagrostis epigeios (L.) Roth & $1.6 / 46$ & $0.9 / 3$ \\
\hline Calamagrostis villosa Gmel. & $11.5 / 69$ & - \\
\hline Calamagrostis sp. & $0.9 / 15$ & - \\
\hline Carex bryzoides L. & $2.3 / 46$ & $7.6 / 6$ \\
\hline $\begin{array}{l}\text { Chamaenerion angustifolium } \\
\text { (L.) Scop. }\end{array}$ & - & $1.2 /$ \\
\hline Cirsium palustre (L.) Scop. & $6.7 / 31$ & \\
\hline Deschampsia caespitosa (L.) P.B. & $0.0 / 8$ & $9.7 /$ \\
\hline Epilobium palustre L. & - & $0.6 /$ \\
\hline Equisetum sp. & - & 0.21 \\
\hline Festuca gigantea (L.) Vill. & $0.1 / 15$ & \\
\hline Frangula alnus Mill. & $1.4 / 23$ & $0.4 /$ \\
\hline Galeopsis tetrachit L. & $0.2 / 8$ & \\
\hline Impatiens parviflora DC. & $5.1 / 77$ & $3.9 /$ \\
\hline $\begin{array}{l}\text { Lysimachia vulgaris } \mathrm{L} \text {. } \\
\text { Majanthemum bifolium }\end{array}$ & & $0.8 /$ \\
\hline (L.) F. W. Schm. & $2.8 / 8$ & - \\
\hline Molinia coerulea (L.) Moench. & $1.7 / 23$ & - \\
\hline Oxalis acetosella L. & $9.7 / 54$ & $3.5 / 33$ \\
\hline Picea excelsa (Lam.) Lk. & $1.7 / 8$ & \\
\hline Populus tremula L. & - & $0.3 /$ \\
\hline Quercus robur $\mathrm{L}$. & & $0.8 /$ \\
\hline Rubus caesius L. & $4.1 / 23$ & \\
\hline Rubus idaeus L. & $10.8 / 54$ & $0.3 / 33$ \\
\hline Rubus sp. & $0.9 / 46$ & - \\
\hline Sambucus nigra L. & $3.3 / 46$ & - \\
\hline Sambucus racemosa L. & $0.8 / 23$ & \\
\hline Scrophularia nodosa L. & & $0.4 / 1$ \\
\hline Senecio Fuchsii Gmel. & $0.3 / 8$ & $0.1 / 17$ \\
\hline Solanum dulcamara L. & $0.1 / 8$ & $0.2 / 17$ \\
\hline Sorbus aucuparia L. & $1.9 / 15$ & - \\
\hline Trientalis europaea L. & $0.5 / 8$ & $3.8 / 33$ \\
\hline Grasses & $7.2 / 92$ & $8.4 / 67$ \\
\hline Bark & $9.4 / 62$ & \\
\hline Seeds and fruits & $0.0 / 8$ & $22.0 / 100$ \\
\hline Fungi & & $26.5 / 50$ \\
\hline Animal food & 2.8 & $1.3 / 17$ \\
\hline Unidentified & $9.8 / 92$ & $6.8 / 83$ \\
\hline
\end{tabular}

At Szczygłowice the percentage of green parts was even higher than that at Aniołki and reached $94 \%$ of the diet. The list of preferred species included Betula sp., Rubus sp., Amalanchier ovalis. In autumn, the fraction of green parts dropped to $56 \%$, with $25 \%$ of seed and fruits and $7 \%$ of fungi. Betula sp. again appeared on the list of preferred plant species which provided green parts (Table 4).

In general, the striped field mouse had the longest list of plant species in the diet (37 species) with most of them found in autumn at Aniołki. 


\subsection{The Yellow-necked Mouse}

The number of plant species whose green parts were eaten by A. flavicollis was much smaller than that in the remaining rodents and cov-

Table 4

Percentage and frequency of occurrence of food components in Apodemus agrarius in spring and autumn at Aniołki and Szczygłowice forest sites. Explanations see Table 2.

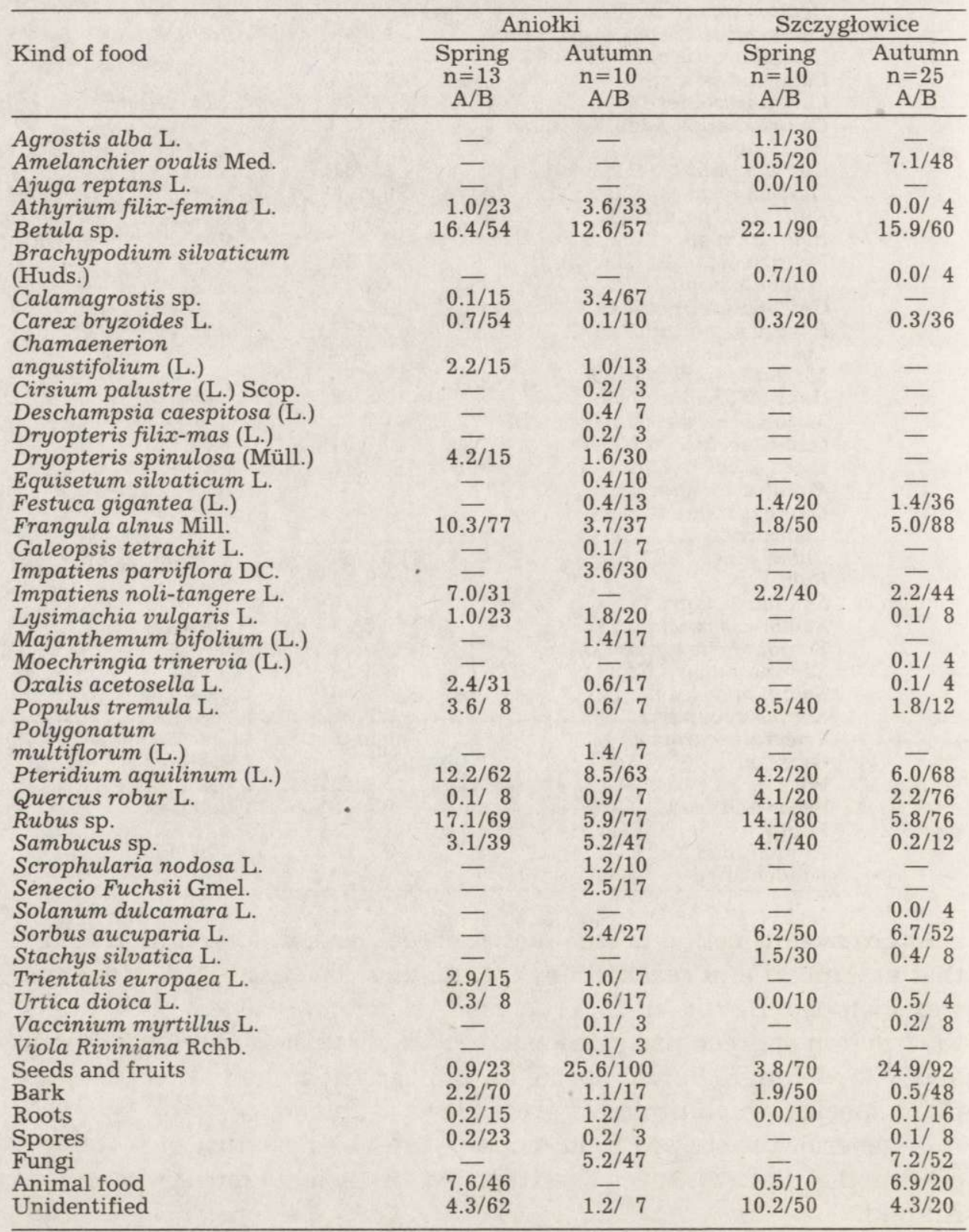


ered 7 to 12 species depending on site and season. In spring at Aniołki the green parts constituted $24 \%$ (with Betula verrucosa), seeds and fruits $19 \%$, rhizomes $5 \%$, and animal food making up $31 \%$ of diet (Table 5 ). In autumn the composition of diet changed to $13 \%$ of green parts, $50 \%$ of seeds and fruits, $31 \%$ of rhizomes, and $3 \%$ of animal food (Table 5 ).

At Szczygłowice, the green parts of plants constituted mere $6 \%$ of the diet. Rhizomes made the bulk of diet $(51.8 \%)$ with animal food $(18.4 \%)$ and tree bark $(4 \%)$. Seeds and fruits were almost absent from the diet $(0.1 \%)$. In autumn, the percentage of green parts dropped still further (to $4 \%$ ), with seeds and fruits, rhizomes, and animal food at 2.51 and $2 \%$, respectively.

There was striking variability in percentages of seeds and fruits, rhizomes, and animal food at both sites during the two seasons. At Szczygłowice the seed and fruits class were absent from spring diet only to make as much as $42 \%$ of in autumn. At Aniołki the percentage of animal food decreased tenfold from spring to autumn, accompanied by a simultaneous increase by six and a half times in percentage of rhizomes (Table 5).

Table 5

Percentage and frequency of occurrence of food components in Apodemus flavicollis in spring and autumn at Aniołki and Szczygłowice forest sites. Explanations see Table 2.

\begin{tabular}{|c|c|c|c|c|}
\hline \multirow[b]{2}{*}{ Kind of food } & \multicolumn{2}{|c|}{ Aniołki } & \multicolumn{2}{|c|}{ Szczygłowice } \\
\hline & $\begin{array}{c}\text { Spring } \\
n=5 \\
\mathrm{~A} / \mathrm{B}\end{array}$ & $\begin{array}{c}\text { Autumn } \\
n=5 \\
\text { A/B }\end{array}$ & $\begin{array}{c}\text { Spring } \\
\mathrm{n}=6 \\
\mathrm{~A} / \mathrm{B}\end{array}$ & $\begin{array}{c}\text { Autumn } \\
n=16 \\
\text { A/B }\end{array}$ \\
\hline Agrostis canina L. & $0.3 / 20$ & - & - & - \\
\hline Amelanchier ovalis Med. & & - & - & $0.1 / 6$ \\
\hline $\begin{array}{l}\text { Betula verrucosa Ehrh. } \\
\text { Calamarostis villosa Gmel. }\end{array}$ & $10.3 / 40$ & $\begin{array}{l}0.1 / 20 \\
3.1 / 40\end{array}$ & $0.2 / 17$ & $\overline{-}$ \\
\hline Carex brizoides L. & $0 . \overline{3 / 20}$ & 3.1/40 & $0.1 / 17$ & $0.1 / 6$ \\
\hline Cirsium palustre (L.) Scop. & - & $0.1 / 20$ & - & - \\
\hline Dryopteris spinulosa (Müll). & $\overline{0}$ & $0.6 / 20$ & $-\overline{0}$ & \\
\hline $\begin{array}{l}\text { Frangula alnus Mill. } \\
\text { Galium saxatile L. }\end{array}$ & $1.8 / 40$ & $\begin{array}{l}0.1 / 20 \\
1.5 / 20\end{array}$ & $5.2 / 83$ & $\underline{0.6 / 19}$ \\
\hline Impatiens noli-tangere $\mathrm{L}$. & - & - & - & $1.2 / 13$ \\
\hline Oxalis acetosella $\mathrm{L}$. & $4.2 / 40$ & - & - & $0.1 / 6$ \\
\hline Picea excelsa (Lam.) Lk. & $\overline{11}$ & $0.1 / 20$ & - & - \\
\hline Pinus silvestris L. & $0.1 / 20$ & $1.3 / 20$ & - & - \\
\hline Pteridium aquilinum(L.) & - & $4.1 / 20$ & 一 & - \\
\hline Rubus caesius L. & - & $0.1 / 60$ & 一 & - \\
\hline Rubus idaeus L. & $7.1 / 80$ & - & - & - \\
\hline Rubus sp. & - & $\overline{1}$ & $0.2 / 17$ & $0.9 / 25$ \\
\hline $\begin{array}{l}\text { Sambucus nigra } \mathrm{L} \text {. } \\
\text { Sambucus racemosa } \mathrm{L} \text {. }\end{array}$ & - & $0.1 / 20$ & $0.1 / 17$ & $0.0 / 6$ \\
\hline $\begin{array}{l}\text { Sambucus racemosa } \mathrm{L} \text {. } \\
\text { Sorbus aucuparia } \mathrm{L} \text {. }\end{array}$ & - & $\underline{1.5 / 20}$ & $0.0 / 17$ & - \\
\hline Seeds and fruits & $19.1 / 60$ & $50.4 / 80$. & $0.1 / 17$ & $41.8 / 88$ \\
\hline Bark & $0.2 / 40$ & $0.4 / 20$ & $4.4 / 33$ & $0.3 / 13$ \\
\hline Underground parts & $4.8 / 100$ & $31.2 / 40$ & $51.8 / 83$ & $51.3 / 81$ \\
\hline Animal food & $31.4 / 100$ & $3.1 / 80$ & $18.4 / 83$ & $2.3 / 63$ \\
\hline Unidentified & $20.4 / 100$ & $2.2 / 80$ & $19.4 / 100$ & $1.3 / 56$ \\
\hline
\end{tabular}




\section{Table 6}

Basic food components, in percentage of occurrence, in four species of rodents at Aniołki and Szczygłowice forest sites.

\begin{tabular}{|c|c|c|c|c|}
\hline \multirow{2}{*}{ Kind of food } & \multicolumn{2}{|c|}{ Aniołki } & \multicolumn{2}{|c|}{ Szczygłowice } \\
\hline & Spring & Autumn & Spring & Autumn \\
\hline \multicolumn{5}{|c|}{ Clethrionomys glareolus } \\
\hline Green parts & 63.5 & 59.3 & 52.4 & 45.3 \\
\hline Seeds and fruits & & & & \\
\hline \multicolumn{5}{|c|}{ Microtus agrestis } \\
\hline Green parts & 78.0 & 43.3 & & \\
\hline Bark & 9.4 & & & \\
\hline Seeds & & 22.0 & & \\
\hline thigt & & & & \\
\hline \multicolumn{5}{|c|}{ Apodemus agrarius } \\
\hline $\begin{array}{l}\text { Green parts } \\
\text { Seeds and fruits }\end{array}$ & 89.1 & $\begin{array}{l}66.8 \\
24.4\end{array}$ & 93.8 & $\begin{array}{l}55.6 \\
24.5\end{array}$ \\
\hline \multirow{2}{*}{\multicolumn{5}{|c|}{ Apodemus flavicollis }} \\
\hline & & & & \\
\hline Seeds and fruits & $\begin{array}{l}4.1 \\
19.2\end{array}$ & & & \\
\hline Underground parts & & 31.1 & 51.8 & 51.2 \\
\hline Animal food & 31.4 & & 18.3 & \\
\hline
\end{tabular}

\section{DISCUSSION}

Since long, the studies carried out in various parts of distribution ranges revealed that the diets of the four rodent species vary in respect to both its composition and the list of preferred plant species. As the changes in diets associated with living in polluted forests of Silesia were species-specific, they should be discussed separately.

The bank vole is a species of an enormously large range of distribution. This implies high variability in diet related to prevailing ecological conditions. Nevertheless, the bank voles always feed principally on the green parts of plants, seeds, and animal food and show seasonal changes in food composition everywhere (for review of trophic status of this species see Gębczyńska, 1983). Both Aniołki and Szczygłowice populations displayed striking stability of the diet without much of seasonality. The green parts of herbaceous plants, grasses, shrubs and trees amounted to $45-65 \%$ and, together with $21-38 \%$ of seeds and fruits make up $80-88 \%$ of total diet irrespective of seasons. In some other, not very, distant regions (environs of Cracow - Zemanek, 1972 and Moravia - Obrtel \& Holišova, 1978), the diets changed along a seasonal rhythm. In lowland forests of Moravia seeds made up 11.7 of spring diet and increased to $34.4 \%$ in autumn (Obrtel \& Holišova, 1978). Even more striking was the difference in animal food category 
which in spring made no more than $1.8 \%$ of diet in Silesia whereas in other populations from Poland (Zemanek, 1972; Gębczyńska, 1976) and from Czechoslovakia (Holišova, 1966; Obrtel \& Holišova, 1978) it reached $7-21 \%$ in spring. Again in the polluted forests in Silesia there have been no basic seasonal changes in the diet of $C$. glareolus found at other sites in autumn. There, the proportion of green parts of forbs, grass, and leaves of shrubs and trees declined drastically while that of seeds and fruits increased. Such shift were observed in Czechoslovakia, Great Britain, Poland, Sweden and on Kola Peninsula of the USSR (Gębczyńska, 1983). At Aniołki and Szczygłowice, the percentage of seeds and fruits did not change much from spring to autumn ( 23 and $21 \%, 36$ and $38 \%$ respectively on the two plots).

Thus, in the diet in bank voles living in polluted forests of Upper Silesia this seasonality disappear. Almost total absence of animal food and reduction in number of species eaten were the remaining features of the diet.

In $M$. agrestis the diet has not been studied in too much detail. It is only known that in Sweden (Hansson, 1971; Stenseth et al., 1977) and Finland (Stenseth et al., 1977) this species feeds upon grasses, forbs and grass seeds. There, a distinct seasonal pattern was found in changes of diet composition. In spring, grasses made about $80 \%$ of diet while in summer and early autumn grasses and forbs shared this amount alnost in halves. Seeds could make as much as $19 \%$ of the diet (Hansscn, 1971), a figure similar to that found at Aniołki site. Treebark that participated $9 \%$ of diet at Aniołki had also been found in studies of M. agrestis in Scandinavia (Stenseth et al., 1977). Only fungi that contributed significantly to the overall diet at Aniołki $(26 \%)$ made rather negligible appearance in the diet of this species at Sweden and Finland.

Some previous reports on $A$. agrarius indicated domination by seeds which were the principal component of the diet (50 to $90 \%$ ) (Holišova, 1967; Babińska-Werka, 1981; Obrtel \& Holišova, 1981).There was also a significant fraction of animal food which, in some cases (Opava region), made $40 \%$ of the diet (Holišova, 1967), and 8 to $12 \%$ in various types of urban green areas (Babińska-Werka, 1981). It was thus quite surprising that one of populations living at Białystok had completely diferent food preferences. Inhabiting the city centre, this population fed mainly on green parts of plants $(71 \%)$, seeds $(19 \%)$, and animal food $(9 \%)$ (Gębczyńska et al.,1987). The trophic relationships found in Aniołki and Szczygłowice populations seem to have altered still further. Green parts of plants constituted as much as 90 and $94 \%$ of spring diets respectively. Not before autumn did seeds and fruits share 
up to $24 \%$ of the diet, with green parts still dominating at $56-67 \%$ of its composition. Also the animal component of diet differed from anything found in that species so far. This kind of food appeared in spring only at Aniołki site (7\%) while in autumn it was simply absent from $A$. agrarius diet at Aniołki and Szczygłowice alike.

Hence both populations of $A$. agrarius at Silesian sites fundamentally changed their food preferences. It is not clear why C. glareolus feeds on seeds on both sites in spring and autumn while A. agrarius refrains from using that kind of food. One may presume that it is spatial interspecific relationships that decide about such arrangement as indicated by a four-year ecological study in the area (Chełkowska et al., 1985). When comparing one of Białystok populations and the two Silesian populations, a hypothesis that this particular species is able to restructure profoundly its diet seems quite viable. It is done by way of modifications in alimentary tract related to the shift from high-energy food to bulk food of low calorific value. The ability to replace highly nutritive seeds and animal food with low-energy green parts of plants is probably based on actual changes in alimentary tract. This physiological plasticity is of fundamental importance for the ecological variability of this murid (Andrzejewski et. al., 1978) enabling it to colonize new habitats such as urban green areas, polluted forests, etc.

Available information about diet of A. flavicollis indicate that it includes mainly seeds and animal food. These categories contribute to the spring diet to the tune of about $40 \%$ each with green parts of plants taking mere $10 \%$ (Obrtel \& Holišova, 1983). It is also known that the yellow-necked mouse feeds on fewer species than, for example, C. glareolus living in the same biotopes (Obrtel \& Holišova, 1974). Our observation at Aniołki and Szczygłowice confirmed these finding as the lists of plant species eaten by A. flavicollis were shorter by half or more than those found in the remaining rodent species. Again, seeds made substantial part of the diet in A. flavicollis. In autumn seeds satisfied 50 and $42 \%$ of feeding requirements at Aniołki and Szczygłowice. The animal food varied widely: although in spring it was about as much as $31 \%$ at Aniołki, and $18 \%$ at Szczygłowice, in autumn dropped to a mere $3 \%$ at both sites. However, there was a significant increase in importance of underground parts of plants which at Szczygłowice provided no less than half of diet, both in spring and autumn. Obrtel and Holišova (1983) found that this kind of food contributed only $4 \%$ of diet in Moravian populations. It should be noted that in polluted Silesian forests this species increased significantly feeding upon underground parts. There were no major shifts in diet although proportions of various kinds of food changed. 
The investigation of rodent diets at Aniołki and Szczygłowice indicated marked changes in food composition (Table 6). In C. glareolus they showed as disappearance of seasonality and withdrawal of animal food. Such depletion of animal food component, found also in other rodent species under study, was undoubtedly associated with decimation of invertebrate fauna at polluted forests (Dąbrowska-Prot 1982). In $M$. agrestis the change was manifested by increased proportion of fungi in diet. A. agrarius has altered its diet completely, turning to green food as basic component and lowering the proportion or even abandoning seeds or animal food. A. flavicollis consumed large quantities of underground parts supplemented by seeds and animal food. There is no doubt that the ability to change diet flexibly allowed A. agrarius inhabit Aniołki and Szczygłowice sites (along with C. glareolus) and reach high numbers there (Walkowa et al.,1982; Chełkowska et al., 1985). It seems that especially $A$. agrarius and $M$. agrestis, the species that normally occur in the Polish forests in rather small numbers, could adopt themselves well to living conditions prevailing in polluted Silesian forests. The differences in population densities found at more degraded forest at Aniołki and less disturbed Szczygłowice site indicate enormous ecological plasticity of $A$. agrarius and high ecological potential of $M$. agrestis. Such were the features that helped them to dominate over C. glareolus and A. flavicollis.

Finally, when starting the research we envisaged relations between the degree of pollution (and indeed the disturbance to the vegetation cover, see Table 1) and the composition of diet in rodents. The only result though is that the sole fact of pollution can force changes in the diet not necessarily proportional to the degree of pollution of actual sites.

Acknowledgements: We would like to extend sincere thanks to Drs W. Walkowa, $\mathrm{K}$. Adamczyk and D. Chełkowska for their help in obtaining material for this study. Ms. I. Jabłonowska identified the diet components in C. glareolus. We are grateful to Dr. R. Tertil for valuable comments on the manuscript.

\section{REFERENCES}

1. Andrzejewski R., Babińska-Werka J., Gliwicz J. \& Goszczyński J., 1978: Synurbization processes in population of Apodemus agrarius. I. Characteristics of populations in an urbanization gradient. Acta theriol., 23: $341-358$.

2. Babińska-Werka J., 1981: Food of the striped field mouse in different types of urban green areas. Acta theriol., 26: 285-299.

3. Celiński F. \& Wika S., 1980: Preliminary studies on degradation of forest habitats near Knurów (Silesia). Pol. ecol. Stud., 4: 593-606.

4. Celiński F., Wika S. \& Baron H., 1982: Vegetation of Knurów town and its surrounding with trends of multiannual changes. Pol. ecol. Stud., 8:241-258

5. Chełkowska H., Walkowa W. \& Adamczyk K., 1985: Spatial relationships in sympa- 
tric populations of the rodents: Clethrionomys glareolus, Microtus agrestis and Apodemus agrarius. Acta theriol., 30: 51-78.

6. Dąbrowska-Prot E., 1982: Structural and functional characteristics of biocenoses in industrial region exemplified by surroundings of the town of Knurów (Upper Silesia). Pol. ecol. Stud., 8: 259-288.

7. Foik H., 1978: Wstępna analiza mikroklimatu i zanieczyszczeń powietrza oraz wód powierzchniowych. Mechanizmy funkcjonowania wybranych krajobrazów Górnośląskiego Okręgu Przemysłowego i Rybnickiego Okręgu Węglowego. - Inst. Ekol. PAN Dziekanów Leśny: 18-31. Mimeogr.

8. Gębczyńska Z., 1976: Food habits of the bank vole and phenological phases of plants in an oak hornbeam forest. Acta theriol., 21: 223-236.

9. Gębczyńska Z., 1983: Feeding habits. [In: "Ecology of the bank vole". ed K. Petrusewicz] Acta theriol., 28 suppl. 1: $40-49$.

10. Gębczyńska Z., Sołtys H. \& Sienkiewicz M., 1987: Food composition in striped field mice living at localities of various degrees of urban development. Acta theriol., 32: $325-330$.

11. Hansson L., 1971: Habitat, food and population dynamics of the field vole, Microtus agrestis (L.) in South Sweden. Viltrevy, 8: 268-378.

12. Holišova V., 1966: Food of an overcrowded population of the bank vole, Clethrionomys glareolus Schreb., in a lowland forest. Zool. listy, 15: 207-224.

13. Holišova V., 1967: The food of Apodemus agrarius (Pall.). Zool. listy, 16:1-14.

14. Obrtel R. \& Holišova V., 1974: Trophic niches of Apodemus flavicollis and Clethrionomys glareolus in a lowland forest. Acta Sc. Nat. Brno, 8:1-37.

15. Obrtel R. \& Holišova V., 1978: Variation in the trophic niche of Clethrionomys glareolus in two different habitats. Folia Zool., 27: 193-202.

16. Obrtel R. \& Holišova V., 1981: The throphic niche of Apodemus agrarius in northern Moravia. Folia Zool., 30: 11-21.

17. Obrtel R. \& Holišova V., 1983: Winter and spring diets of three coexisting Apodemus spp. Folia Zool., 32: 291-302.

18. Stenseth N. C., Hansson L. \& Myllymäki A., 1977: Food selection of the field vole, Microtus agrestis. Oikos, 29: 511-524.

19. Walkowa W., Adamczyk K. \& Chełkowska K., 1982: Numbers and structure of rodent communities in the forest environment of Silesia. Pol. ecol. Stud., 8: 305-330.

20. Warteresiewicz M., 1979: Oddziaływanie zanieczyszczenia powietrza dwutlenkiem siarki na wybrane gatunki roślin w rejonie górnośląskiego okręgu przemysłowego. Arch. Ochr. Środ., 1: 95-166.

21. Zemanek M., 1972: Food and feeding habits of rodents in a deciduous forest. Acta theriol., 17: $315-325$.

Received 11 January 1989, Accepted 24 June 1989. 


\section{Zofia GĘBCZYŃSKA, Marek GĘBCZYŃSKI, Krystyna MORZUCH} i Dorota M. ZIELIŃSKA

\section{POKARM CZTERECH GATUNKÓW GRYZONI BYTUJACYCH W ZANIECZYSZCZONYCH LASACH}

\section{Streszczenie}

Badania prowadzono w Rybnickim Okręgu Węglowym (górny Śląsk) w lasach obok Aniołków i Szczygłowic. Na obu obszarach dominują silnie zanieczyszczone i zdegradowane zespoły Tilio-Carpinetum, przy czym w rejonie Aniołków zmiany w środowisku są większe (Tabela 1). Próby do oznaczania diety u Clethrionomys glareolus, Apodemus agrarius i Apodemus flavicollis pozyskiwane były wiosną i jesienią na obu powierzchniach, a okazy Microtus agrestis łapane były w obu sezonach, ale tylko koło Aniołków.

Clethrionomys glareolus odżywia się podobnym pokarmem (tak samo jak i dwa pozostałe gatunki) na obu powierzchniach. Pokarm tego gatunku składa się głównie z zielonych części roślin ( $45-65 \%)$ oraz nasion i owoców $(21-38 \%)$. Brak tu jest natomiast pokarmu pochodzenia zwierzęcego (Tabela 2), a także nie zaznaczają się zmiany sezonowe. Obie te cechy różnią dietę $C$. glareolus ze Śląska w porównaniu do wszystkich innych poznanych populacji tego gatunku.

Microtus agrestis ma na Śląsku podobny skład pokarmu jak na innych obszarach swego występowania; wiosną pokarm zielony stanowi $78 \%$ diety, a jesienią $43 \%$. Udział nasion jesienią wynosi $22 \%$. Natomiast grzyby stanowią jesienią aż $26 \%$ diety (Tabela 3 ), co jest cechą właściwą tylko tej populacji.

Apodemus agrarius na Śląsku odżywia się głównie zielonymi częściami roślin, które wiosną stanowią $90-94 \%$ składu diety, zaś jesienią ich udział wynosi $56-67 \%$. Nasiona w tym sezonie stanowią $24 \%$ (Tabela 4). Oznacza to przebudowę stosunków pokarmowych w porównaniu do większości poznanych populacji tego gatunku gryzonia, gdzie podstawą diety są nasiona.

Apodemus flavicollis w obu populacjach w lasach Śląska żywi się nasionami i pokarmem pochodzenia zwierzęcego, czyli podobnie jak w innych zbadanych dotychczas populacjach tego gatunku. Natomiast na Śląsku w pokarmie myszy leśnej wzrasta, do $50 \%$ objętości diety, udział podziemnych części roślin (Tabela 5) co stanowi swoistość w porównaniu z innymi poznanymi populacjami tego gatunku.

Ogólnie zatem można powiedzieć, że u wszystkich gatunków gryzoni zamieszkujących silnie zdegradowane pod wpływem zanieczyszczeń lasy na Śląsku, nastąpiły zmiany w składzie diety $\mathrm{w}$ porównaniu do populacji bytujących $\mathrm{w}$ środowiskach naturalnych lub nie tak silnie odkształconych. U C. galerolus, M. agrestis i A. flavicollis wyrażają się one zmianą udziału poszczególnych składników diety, natomiast u A. agrarius nastąpiła wyraźna zmiana preferencji pokarmowych (Tabela 6). Zmiana diety u zbadanych gatunków nie była zależna od stopnia zanieczyszczenia (Tabela 1) obu powierzchni, zatem można sądzić, że sam fakt odkształceń szaty roślinnej już powoduje przebudowę stosunków pokarmowych gryzoni bez zachowania spodziewanej proporcji do zmian środowiska. 